\title{
Factors of Response to Pegylated Interferon/ Ribavirin Combination Therapy and Mechanism of Viral Clearance
}

\author{
Kayo Sugimoto ${ }^{a}$ Soo Ryang Kim ${ }^{b}$ Ahmed El-Shamy ${ }^{c}$ Susumu Imoto ${ }^{b}$ \\ Kenji Ando ${ }^{b}$ Ke Ih Kim ${ }^{a}$ Yasuhito Tanakag Yoshihiko Yano ${ }^{d}$ Soo Ki Kim ${ }^{\text {h }}$ \\ Yutaka Hasegawa $^{e}$ Aya Fujinami ${ }^{f}$ Mitsuhiro Ohtaf Hatae Takashie \\ Hak Hottac $^{c}$ Yoshitake Hayashid Masatoshi Kudoi \\ Departments of a Pharmacy and ${ }^{b}$ Gastroenterology, Kobe Asahi Hospital, ' Department of Microbiology and \\ ${ }^{\mathrm{d}}$ Division for infectious Disease Pathology, Center for Infectious Diseases, Kobe University Graduate School of \\ Medicine, and ${ }^{e}$ Educational Center for Clinical Pharmacy and ${ }^{f}$ Medical Biochemistry, Kobe Pharmaceutical \\ University, Kobe, 9 Department of Virology and Liver Unit, Nagoya City University Graduate School of \\ Medical Sciences, Nagoya, h Department of Gastroenterology, Kyoto University, Kyoto, and 'Department of \\ Gastroenterology and Hepatology, Kinki University School of Medicine, Osakasayama, Japan
}

\section{Key Words}

Viral clearance $\cdot$ Interferon $\lambda 1 \cdot$ Pegylated interferon ·

Ribavirin · Interleukin 28B · Interferon and ribavirin resistance-determining region $\cdot$ Interferon

sensitivity-determining region

\begin{abstract}
Objectives: This study explores viral factors of the interferon (IFN) and ribavirin (RBV) resistance-determining region (IRRDR), the IFN sensitivity-determining region (ISDR) and the core protein, and host factor interleukin 28B associated with response to pegylated IFN (PEG-IFN) and RBV combination therapy, and the correlation of viral and host factors with IFN- $\lambda$ 1. Methods: A total of 58 patients underwent PEGIFN/RBV combination therapy for 48 weeks. The pretreatment factors associated with rapid virological response (RVR) and sustained virological response (SVR) were analyzed. Pretreatment IFN- $\lambda 1$ serum levels were compared with the viral and host factors. Results: Univariate analysis
\end{abstract}

\section{KARGER}

E-Mail karger@karger.com

www.karger.com/ddi showed that IRRDR $\geq 6$ and ISDR $\geq 2$ were significant pretreatment predictors of RVR, and multivariate analysis identified IRRDR $\geq 6$ and hemoglobin as significant predictors of SVR. Pretreatment IFN- $\lambda 1$ was significantly higher in the SVR group than in the non-SVR group and also in the IRRDR $\geq 6$ group than in the IRRDR $\leq 5$ group. Conclusions: IRRDR $\geq 6$ was the only significant predictor of SVR and was correlated with IFN- $\lambda 1$. High serum levels of IFN- $\lambda 1$ may be conducive to effective PEG-IFN/RBV combination therapy because of the immunomodulatory system.

(c) 2013 S. Karger AG, Basel

\section{Introduction}

Although the triple therapy of combined pegylated interferon (PEG-IFN), ribavirin (RBV) and protease inhibitors has already been initiated, PEG-IFN and RBV combination therapy for chronic hepatitis $\mathrm{C}$ virus (HCV) infection with a high viral load of genotype $1 \mathrm{~b}$, the standard 
treatment in Japan since 2004, provides sustained virological response (SVR) in only approximately $50 \%$ of such patients [1]. Single-nucleotide polymorphisms in proximity to the interleukin 28B (IL-28B) gene (rs8099917, rs12979860) on chromosome 19 is reported to be a host-related factor of virological response to PEG-IFN and RBV combination therapy [2-4]. In recent years, viral factors such as the core protein, nonstructural protein $5 \mathrm{~A}$ (NS5A), the IFN sensitivity-determining region (ISDR) and the IFN/RBV resistance-determining region (IRRDR) [4-8] have been associated with virological response. Nonetheless, the mechanism of how these host and viral factors affect viral clearance has not been precisely elucidated to date.

IFN- $\lambda 1$ is considered to be associated with the inhibition of the replication of $\mathrm{HCV}$ by an immunological mechanism $[9,10]$. Few studies, however, have demonstrated the correlation among IFN- $\lambda 1$ serum levels, the clinical outcome of PEG-IFN and RBV combination therapy, and viral and host factors. We investigated the viral and host factors associated with response to PEGIFN and RBV combination therapy and the correlation of viral and host factors with IFN- $\lambda 1$.

\section{Patients and Methods}

\section{Patients}

A total of 58 patients ( 32 men, 26 women; age $57.3 \pm 10.4$ years) seen at Kobe Asahi Hospital and diagnosed with chronic HCV and high viral loads of genotype $1 \mathrm{~b}$ were enrolled in the study. Patients demonstrating hemoglobin levels $\geq 11 \mathrm{~g} / \mathrm{dl}$ (women) or $\geq 12 \mathrm{~g} / \mathrm{dl}$ (men), platelet count $\geq 9 \times 10^{4} / \mathrm{mm}^{3}$, HCV RNA $\geq 5.0 \log \mathrm{IU} / \mathrm{ml}$, neutrophil count $\geq 1,500 / \mathrm{mm}^{3}$ and thyroid-stimulating hormone levels within normal limits were included in the study; those demonstrating human immunodeficiency virus or hepatitis B coinfection, creatinine clearance $<50 \mathrm{ml} / \mathrm{min}$, liver disease other than chronic hepatitis $\mathrm{C}$, evidence of advanced liver disease, preexisting psychiatric conditions, or a history of severe psychiatric disorder were excluded.

Treatment comprised PEG-IFN- $\alpha 2 b(1.5 \mu$ g per kilogram body weight, once a week) plus RBV (600-1,000 mg daily, based on body weight) for a total of 48 weeks, according to the standard treatment protocol for Japanese patients. Informed written consent was obtained from each patient and the study protocol conformed to the ethical guidelines approved by the Ethics Committee of Kobe Asahi Hospital.

\section{Laboratory Tests}

HCV RNA was extracted from $140 \mu$ of serum with the use of a commercially available kit (QIAmp viral RNA kit; Qiagen, Tokyo, Japan). Amplification of full-length NS5A and the core regions of the HCV genome was carried out as described [5]. The sequences of the amplified fragments of NS5A and the core regions
Table 1. Patient baseline characteristics

$\begin{array}{lc}\text { Age (years) } & 57.3 \pm 10.4 \\ \text { Sex (male/female) } & 34 / 24 \\ \text { BMI } & 22.6 \pm 3.8 \\ \text { HCV-RNA }(\log \mathrm{IU} / \mathrm{ml}) & 6.0 \pm 0.6 \\ \text { ALT }(\mathrm{U} / \mathrm{l}) & 54.8 \pm 64.0 \\ \gamma \text {-GTP }(\mathrm{U} / \mathrm{l}) & 57.0 \pm 64.7 \\ \text { Hemoglobin }(\mathrm{g} / \mathrm{dl}) & 13.7 \pm 1.98 \\ \text { Platelets }\left(\times 10^{4} / \mathrm{mm}^{3}\right) & 16.0 \pm 5.0 \\ \text { Total cholesterol }(\mathrm{mg} / \mathrm{dl}) & 174.0 \pm 34.0 \\ \text { IL-28B }(\mathrm{major} / \mathrm{minor}) & 43 / 15 \\ \text { IFN- } \lambda 1(\mathrm{pg} / \mathrm{ml}) & 31.0 \pm 24.2 \\ \text { ISDR }(\geq 2 / \leq 1) & 14 / 44 \\ \text { IRRDR }(\geq 6 / \leq 5) & 22 / 36 \\ \text { Core aa } 70(\text { arginine/glutamine }) & 39 / 19 \\ \text { Core aa } 91(\text { leucine/methionine }) & 39 / 19\end{array}$

Data are shown as number $(n)$ or mean \pm SD.

were determined by direct sequencing without subcloning. The amino acid (aa) sequences were deduced and aligned with the use of GENETYX Win software version 7.0 (GENETYX Corp., Tokyo, Japan). Genetic polymorphism rs8099917 around the IL-28B gene was determined by real-time PCR using the TaqMan assay. We defined the IL-28B major allele as homozygous (TT) for the major sequence and the minor allele as homozygous (GG) or heterozygous (TG) for the minor sequence. IFN- $\lambda 1$ was assayed before initiation of therapy and at 4,12 and 48 weeks after therapy by ELISA Ready-SET-Go (unit, pg/ml; NatuTec, Frankfurt, Germany).

\section{Statistical Analysis}

Rapid virological response (RVR) and SVR were defined as undetectable HCV RNA at weeks 4 and 24, respectively, after treatment. The potential pretreatment factors associated with virological response and comprising age, sex, BMI, HCV RNA load, alanine aminotransferase (ALT), $\gamma$-glutamyl transpeptidase ( $\gamma$-GTP), hemoglobin, platelets, IFN- $\lambda 1$, single-nucleotide polymorphisms in the IL-28B gene region, mutations in NS5A - especially those in ISDR (ISDR $\geq 2$ and ISDR $\leq 1$ ) and IRRDR (IRRDR $\geq 6$ and IRRDR $\leq 5)$ - and mutated core protein amino acid substitutions at aa 70 of arginine (Arg70), or glutamine (Gln70), and at aa 91 of leucine (Leu91), or methionine (Met91), were examined. Factors associated with virological response were assessed by univariate analysis using Student's t test, Fisher's exact test or $\chi^{2}$ test, and by multivariate analysis using logistic regression analysis. The factors in multivariate logistic regression analysis were included in descending order according to correlativity. The most appropriate model was chosen by AIC (Akaike Information Crietion). We compared pretreatment IFN- $\lambda 1$ in the IRRDR $\geq 6$ and IRRDR $\leq 5$ groups, in the ISDR $\geq 2$ and ISDR $\leq 1$ groups, in the IL-28B TT genotype for the major sequence and in the IL-28B GG genotype and TG genotype for the minor sequence, and in the core protein (aa 70 and aa 91 ) wild and mutant. Variables with a p value $<0.05$ were considered statistically significant. All statistical analyses were carried out with the use of Excel Statistics 2011 by SSRI. 
Table 2. Correlation of baseline characteristics with clinical outcome of RVR and non-RVR

\begin{tabular}{lccl}
\hline & RVR & Non-RVR & p value \\
\hline Age (years) & $48.6 \pm 6.2$ & $58.2 \pm 10.7$ & 0.054 \\
Sex (male/female) & $4 / 1$ & $27 / 23$ & 0.373 \\
BMI & $21.8 \pm 1.5$ & $22.9 \pm 4.0$ & 0.536 \\
HCV-RNA (log IU/ml) & $5.8 \pm 0.8$ & $6.0 \pm 0.56$ & 0.303 \\
ALT $(\mathrm{U} / \mathrm{l})$ & $141.4 \pm 178.9$ & $47.2 \pm 36.2$ & 0.304 \\
$\gamma$-GTP $(\mathrm{U} / \mathrm{l})$ & $99.6 \pm 67.9$ & $49.7 \pm 61.0$ & 0.090 \\
Hemoglobin $(\mathrm{g} / \mathrm{dl})$ & $14.0 \pm 1.7$ & $13.7 \pm 1.8$ & 0.707 \\
Platelets $\left(\times 10^{4} / \mathrm{mm}^{3}\right)$ & $16.0 \pm 5.8$ & $16.0 \pm 4.8$ & 0.982 \\
Total cholesterol $(\mathrm{mg} / \mathrm{dl})$ & $158 \pm 30.2$ & $174.6 \pm 34.1$ & 0.354 \\
IL-28B $(\mathrm{major} / \mathrm{minor})$ & $5 / 0$ & $35 / 15$ & 0.308 \\
IFN- $\lambda 1(\mathrm{pg} / \mathrm{ml})$ & $24.9 \pm 10.4$ & $31.3 \pm 25.3$ & 0.582 \\
ISDR $(\geq 2 / \leq 1)$ & $4 / 1$ & $10 / 40$ & $\mathbf{0 . 0 1 2}$ \\
IRRDR $(\geq 6 / \leq 5)$ & $5 / 0$ & $15 / 35$ & $\mathbf{0 . 0 0 4}$ \\
Core aa 70 & & & \\
$\quad$ arginine/glutamine & $3 / 2$ & $32 / 16$ & 1 \\
Core aa 91 $\quad$ & & \\
$\quad$ leucine/methionine & $4 / 1$ & $33 / 17$ & 1 \\
\hline
\end{tabular}

Data are shown as number $(n)$ or mean \pm SD. Bold $p$ values are significant.

\section{Results}

Patient baseline characteristics are listed in table 1 . RVR was observed in $8.6 \%(5 / 58)$ and SVR in $44.8 \%$ $(26 / 58)$ of the patients. ISDR $\geq 2$ and IRRDR $\geq 6$ were significantly associated with RVR as assessed by univariate analysis ( $\mathrm{p}=0.012, \mathrm{p}=0.004$; table 2 ). IRRDR $\geq 6$ was most significantly correlated with RVR, which was from biased data of distribution (table 2). As a result, we were not able to conduct multivariate analysis for RVR. By univariate analysis, the significant factors associated with SVR were age, sex, hemoglobin, IL-28B major, IRRDR $\geq 6$ $(\mathrm{p}=0.015, \mathrm{p}=0.016, \mathrm{p}<0.001, \mathrm{p}=0.006, \mathrm{p}<0.001, \mathrm{p}=$ 0.037 ; table 3$)$. The pretreatment IFN- $\lambda 1$ serum level in SVR was significantly higher than in non-SVR ( 38.8 vs. $24.7 \mathrm{pg} / \mathrm{ml}, \mathrm{p}=0.037$; table 3 ). By multivariate analysis, hemoglobin and IRRDR $\geq 6$ were significantly associated with SVR ( $p=0.02, p=0.005$; table 4). Pretreatment IFN- $\lambda 1$ was significantly higher in the IRRDR $\geq 6$ group than in the IRRDR $\leq 5$ group ( 40.5 vs. $25.2 \mathrm{pg} / \mathrm{ml}, \mathrm{p}=$ 0.041 ; fig. 1), but demonstrated no significant difference between the ISDR $\geq 2$ group and the ISDR $\leq 1$ group ( 37.2 vs. $29.1 \mathrm{pg} / \mathrm{ml}, \mathrm{p}=0.45$; fig. 1 ), among the IL-28B TT genotype group, the TG genotype group and the GG genotype group (TT vs. TG, 33.4 vs. $24.6 \mathrm{pg} / \mathrm{ml}, \mathrm{p}=0.26$; TT vs. $\mathrm{GG}, 33.4$ vs. $20.8 \mathrm{pg} / \mathrm{ml}, \mathrm{p}=0.48$; TG vs. $\mathrm{GG}, 24.6$ vs.
Table 3. Correlation of baseline characteristics with clinical outcome of SVR and non-SVR

\begin{tabular}{lccc}
\hline & SVR & Non-SVR & p value \\
\hline Age (years) & $53.7 \pm 10.1$ & $60.3 \pm 9.9$ & $\mathbf{0 . 0 1 5}$ \\
Sex (male/female) & $20 / 6$ & $14 / 18$ & $\mathbf{0 . 0 1 6}$ \\
BMI & $23.0 \pm 3.7$ & $22.3 \pm 3.9$ & 0.484 \\
HCV-RNA (log IU/ml) & $5.9 \pm 0.7$ & $6.1 \pm 0.5$ & 0.300 \\
ALT $(\mathrm{U} / \mathrm{l})$ & $54.0 \pm 38.8$ & $55.6 \pm 79.5$ & 0.926 \\
$\gamma$-GTP $(\mathrm{U} / \mathrm{l})$ & $72.2 \pm 87.6$ & $44.6 \pm 33.8$ & 0.14 \\
Hemoglobin $(\mathrm{g} / \mathrm{dl})$ & $14.6 \pm 1.5$ & $13.0 \pm 1.6$ & $<\mathbf{0 . 0 1}$ \\
Platelets $\left(\times 10^{4} / \mathrm{mm}^{3}\right)$ & $17.1 \pm 4.8$ & $15.2 \pm 5.0$ & 0.135 \\
Total cholesterol $(\mathrm{mg} / \mathrm{dl})$ & $173.5 \pm 33.2$ & $174.3 \pm 35.0$ & 0.941 \\
IL-28B (major/minor) & $24 / 2$ & $19 / 3$ & $\mathbf{0 . 0 0 6}$ \\
IFN- 1 ( $(\mathrm{pg} / \mathrm{ml})$ & $38.8 \pm 29.3$ & $24.7 \pm 17.2$ & $\mathbf{0 . 0 3 7}$ \\
ISDR $(\geq 2 / \leq 1)$ & $8 / 18$ & $6 / 26$ & 0.36 \\
IRRDR $(\geq 6 / \leq 5)$ & $18 / 8$ & $4 / 28$ & $<\mathbf{0 . 0 1}$ \\
Core aa 70 & & & \\
$\quad$ arginine/glutamine & $20 / 5$ & $17 / 14$ & 0.087 \\
Core aa 91 & & & \\
$\quad$ leucine/methionine & $19 / 7$ & $20 / 12$ & 0.412 \\
\hline
\end{tabular}

Data are shown as number $(\mathrm{n})$ or mean $\pm \mathrm{SD}$. Bold $\mathrm{p}$ values are significant.

Table 4. Factors associated with SVR by multivariate analysis

\begin{tabular}{lcll}
\hline & Odds ratio & $95 \% \mathrm{CI}$ & $\mathrm{p}$ value \\
\hline Age (years) & 0.9247 & $0.85-1.01$ & 0.0678 \\
Sex & 5.4742 & $0.44-68.64$ & 0.1876 \\
Hemoglobin & 2.4704 & $1.12-5.43$ & $\mathbf{0 . 0 2 4 4}$ \\
IL-28B (major/minor) & 5.1960 & $0.60-45.10$ & 0.1350 \\
IFN- $\lambda 1$ (pg/ml) & 1.0230 & $0.98-1.07$ & 0.2758 \\
IRRDR ( $\geq 6 / \leq 5)$ & 16.9320 & $2.39-119.77$ & $\mathbf{0 . 0 0 4 6}$ \\
\hline
\end{tabular}

Bold $\mathrm{p}$ values are significant.

$20.8 \mathrm{pg} / \mathrm{ml}, \mathrm{p}=0.82$; fig. 1 ), and between core protein wild and mutant of aa 70 and aa 91 (aa 70 wild vs. mutant, 30.8 vs. $30.0 \mathrm{pg} / \mathrm{ml}, \mathrm{p}=0.91$; aa 91 wild vs. mutant, 34.6 vs. 23.7 $\mathrm{pg} / \mathrm{ml}, \mathrm{p}=0.05$; fig. 1 ).

\section{Discussion}

Pretreatment factors significantly and independently predictive of the outcome of treatment of patients infected with high viral loads of HCV-1b are IL-28B major genotype (TT) as a host factor [11], and substitutions of aa 70 


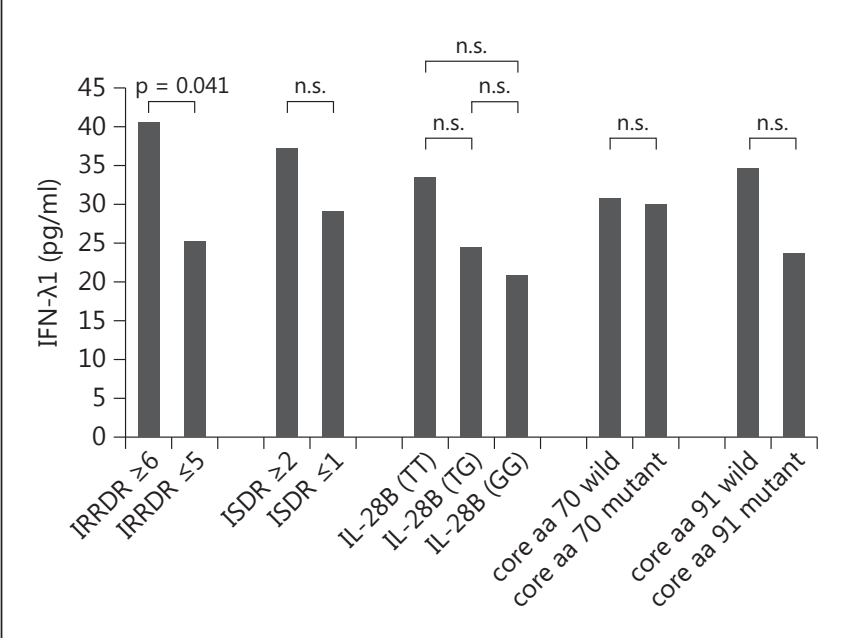

Fig. 1. Comparison of IFN $-\lambda 1$ in the IRRDR $\geq 6$ and IRRDR $\leq 5$, ISDR $\geq 2$ and ISDR $\leq 1$, IL-28B, core aa 70 and core aa 91 . Pretreatment IFN- $\lambda 1$ was significantly higher in the IRRDR $\geq 6$ group than in the IRRDR $\leq 5$, but demonstrated no significant difference between the ISDR $\geq 2$ group and the ISDR $\leq 1$ group, among the IL-28B TT genotype group, the GG genotype group and the TG genotype group, between core protein wild and mutant of aa 70 and aa 91 .

and aa 91 in the HCV core region, and high sequence variations in IRRDR $(\geq 6)$ and in ISDR $(\geq 2)$ as viral factors [4, $5,7,8,11]$. By univariate analysis, our study showed that ISDR and IRRDR were significant pretreatment predictors of RVR, and by multivariate analysis that IRRDR and hemoglobin were significant predictors of SVR. Because of the small number of RVR patients in our data, we were not able to carry out multivariate analysis for identifying RVR predictors. Our results support a previous study [12], and by univariate analysis we demonstrated a significant correlation between high pretreatment IFN- $\lambda 1$ serum levels and SVR, but were unable to do so by multivariate analysis. On the other hand, although we were unable to demonstrate IL-28B as a predictor of SVR, some studies have demonstrated it as a positive predictive factor $[2,13,14]$.

The level of IFN- $\lambda 1$ has been reported to be significantly higher in carriers of the IL-28B major genotype than in those of the IL-28B homozygous minor sequence [9]. In the present study, the level of serum IFN- $\lambda 1$ was higher in carriers of the IL-28B major genotype (TT) than in those of the IL-28B homozygous (GG) and the heterozygous (TG) minor sequence, but not significantly different $(\mathrm{p}=0.48, \mathrm{p}=0.26)$. Because the number of carriers of the IL-28B homozygous allele (GG) was small $(n=2)$, we compared the level of serum IFN- $\lambda 1$ in the IL-28B major homozygous allele (TT) and in the IL-28B minor homozygous (GG) as well as in the heterozygous (TG) allele. Nonetheless, for unclear reasons, no significant association was observed between a high level of serum IFN- $\lambda 1$ and IL-28B major (major $33.4 \mathrm{pg} / \mathrm{ml}$, minor $24.1 \mathrm{pg} / \mathrm{ml}$; $\mathrm{p}=0.20$; data not shown). Further study is needed to clarify the relation between IL-28B and IFN- $\lambda 1$.

It is well known that the antiviral mechanism of IFN comprises two phases $[15,16]$. The first is direct inhibition of viral replication mediated by a number of proteins induced through the activation of the JAK-STAT pathway, including double-stranded RNA-activated protein kinase, myxovirus resistance gene A and 2',5'-oligoadenylate synthetase, which block translation, block replication and degrade viral RNA, respectively [17-21]. The second is an indirect antiviral mechanism mediated by the stimulation of the host cell-mediated immune function including the cytotoxic $\mathrm{T}$ cell. The fact that IFN- $\lambda 1$ significantly downregulates the secretion of IL- 13 but elevates IFN- $\gamma$ suggests that IFN- $\lambda 1$ is related to an elevation of the Th1 response accompanied with a decrease of the Th2 response [10]. High levels of IFN- $\lambda 1$ predispose to spontaneous resolution of $\mathrm{HCV}$ infection because of an elevation of the Th1 response [9]. Also, IFN- $\lambda 1$ upregulates the chemokines MIG (Monokine induced by IFN- $\gamma$ ), IP-10 (IFN- $\gamma$-inducible protein 10$)$ and I-TAC (IFN-inducible T cell $\alpha$-chemoattractants), which are antimicrobial chemoattractants in peripheral blood mononuclear cells [22]. Taken together, these data suggest that IFN- $\lambda 1$ stimulates the immunomodulatory effect [23].

The epitope located at position 2416, at a distance of 37 aa from IRRDR has been identified as an HLA-A26 CD8+ $\mathrm{T}$ cell epitope [24], which was targeted in all patients examined with acute resolving HCV infection. Therefore, IRRDR is regarded as the area (NS5A) related to immune function [5]. Our data demonstrated that IRRDR was significantly associated with IFN- $\lambda 1$. From the above results, we infer that the achievement of SVR in patients with high IFN- $\lambda 1$ levels is associated with the immunomodulatory system. Because of the small number of patients in our study, analysis in a large-scale multicenter study is needed.

\section{Acknowledgment}

We are indebted to Ms. Yoshiko Kawamura of Kobe Asahi Hospital for assistance in the preparation of the manuscript.

\section{Disclosure Statement}

The authors have no conflicts of interest to declare. 


\section{References}

1 Kurosaki M: How to control HCV-related HCC: a personalized strategy. Liver Cancer 2013,2:167.

2 Ge D, Fellay J, Thompson AJ, Simon JS, Shianna KV, Urban TJ, Heinzen EL, Qiu P, Bertelsen AH, Muir AJ, Sulkowski M, McHutchison JG, Goldstein DB: Genetic variation in IL28B predicts hepatitis $C$ treatment-induced viral clearance. Nature 2009;461:399-401.

-3 Thompson AJ, Muir AJ, Sulkowski MS, Ge D, Fellay J, Shianna KV, Urban T, Afdhal NH, Jacobson IM, Esteban R, Poordad F, Lawitz EJ, McCone J, Shiffman ML, Galler GW, Lee WM, Reindollar R, King JW, Kwo PY, Ghalib RH, Freilich B, Nyberg LM, Zeuzem S, Poynard T, Vock DM, Pieper KS, Patel K, Tillmann HL, Noviello S, Koury K, Pedicone LD, Brass CA, Albrecht JK, Goldstein DB, McHutchison JG: Interleukin-28B polymorphism improves viral kinetics and is the strongest pretreatment predictor of sustained virologic response in genotype 1 hepatitis $\mathrm{C}$ virus. Gastroenterology 2010;139:120-129.

-4 Enomoto N, Sakuma I, Asahina Y, Kurosaki M, Murakami T, Yamamoto C, Ogura Y, Izumi N, Marumo F, Sato C: Mutations in the nonstructural protein $5 \mathrm{~A}$ gene and response to interferon in patients with chronic hepatitis $C$ virus $1 b$ infection. $N$ Engl J Med 1996 334:77-81.

5 El-Shammy A, Nagano-Fujii M, Sasase N, Imoto S, Kim SR, Hotta H: Sequence variation in hepatitis $\mathrm{C}$ virus nonstructural protein $5 \mathrm{~A}$ predicts clinical outcome of pegylated interferon/ribavirin combination therapy. Hepatology 2008;48:38-47.

6 Fukuhara T, Taketomi A, Okano S, Ikegami T, Soejima Y, Shirabe K, Maehara Y: Mutations in hepatitis $\mathrm{C}$ virus genotype $1 \mathrm{~b}$ and the sensitivity of interferon-ribavirin therapy after liver transplantation. J Hepatol 2010;42 672-680.

7 Akuta N, Suzuki F, Kawamura Y, Yatsuji H, Sezaki H, Suzuki Y, Hosaka T, Kobayashi M, Kobayashi M, Arase Y, Ikeda K, Kumada H: Predictors of viral kinetics to peginterferon plus ribavirin combination therapy in Japanese infected with hepatitis $C$ virus genotype 1b. J Med Virol 2007;79:1686-1695.

${ }_{8}$ Akuta N, Suzuki F, Kawamura Y, Yatsuji H, Sezaki H, Suzuki Y, Hosaka T, Kobayashi M, Kobayashi M, Arase Y, Ikeda K, Kumada H: Predictive factors of early and sustained re- sponses to peginterferon plus ribavirin combination therapy in Japanese patients infected with hepatitis $C$ virus genotype $1 \mathrm{~b}$ : amino acid substitutions in the core region and lowdensity lipoprotein cholesterol levels. J Hepatol 2007;46:403-410.

-9 Langhans B, Kupfer B, Braunschweiger I, Arndt S, Schulte W, Nischalke HD, Nattermann J, Oldenburg J, Sauerbruch T, Spengler U: Interferon-lambda serum levels in hepatitis C. J Hepatol 2011;54:859-865.

10 Srinvas S, Dai J, Gallagher GE, Megjugorac $N J$, Gallagher G: Interferon- $\lambda 1$ (interloukin-29) preferentially down-regulates interleukin-13 over other T helper type 2 cytokine responses in vitro. Immunology 2008; 125:492-502.

11 Kurosaki M, Tanaka Y, Nishida N, Sakamoto N, Enomoto N, Honda M, Sugiyama M, Matsuura K, Sugauchi F, Asahina Y, Nakagawa M, Watanabe M, Sakamoto M, Maekawa S, Sakai A, Kaneko S, Ito K, Masaki N, Tokunaga K, Izumi N, Mizokami M: Pre-treatment prediction of response to pegylated interferon plus ribavirin for chronic hepatitis $\mathrm{C}$ using genetic polymorphism in IL28B and viral factors. J Hepatol 2011;54:439-448.

12 Kim SR, El-Sharmy A, Imoto S, Kim KI, Ide YH, Deng L, Shoji I, Tanaka Y, Hasegawa Y, Ota M, Hotta H: Prediction of response to pegylated interferon/ribavirin combination therapy for chronic hepatitis $\mathrm{C}$ genotype $\mathrm{1b}$ and high viral load. J Gastroenterol 2012;24: 1143-1151.

13 Tanaka Y, Nishida N, Sugiyama M, Kurosaki M, Matsuura K, Sakamoto N, Nakagawa M, Korenaga M, Hino K, Hige S, Ito Y, Mita E, Tanaka E, Mochida S, Murawaki Y, Honda M, Sakai A, Hiasa Y, Nishiguchi S, Koike A, Sakaida I, Imamura M, Ito K, Yano K, Masaki N, Sugauchi F, Izumi N, Tokunaga K, Mizokami M: Genome-wide association of IL28B with response to pegylated interferon-alpha and ribavirin therapy for chronic hepatitis $\mathrm{C}$. Nat Genet 2009;41:1105-1109.

14 Suppiah V, Moldovan M, Ahlenstiel G, Berg T, Weltman M, Abate ML, Bassendine M, Spengler U, Dore GJ, Powell E, Riordan S, Sheridan D, Smedile A, Fragomeli V, Müller T, Bahlo M, Stewart GJ, Booth DR, George J: IL28B is associated with response to chronic hepatitis $\mathrm{C}$ interferon-alpha and ribavirin therapy. Nat Genet 2009;41:1100-1104.
15 Neumann AU, Lam NP, Dahari H, Gretch DR, Wiley TE, Layden TJ, Perelson AS: Hepatitis $C$ viral dynamics in vivo and the antiviral efficacy of interferon-alpha therapy. Science 1998;282:103-107.

-16 Yasui K, Okanoue T, Murakami M, Itoh Y, Minami M, Sakamoto S, Sakamoto M, Nishioji K: Dynamics of hepatitis C viremia following interferon-alpha administration. J Infect Dis 1998;177:1475-1479.

17 Schmidt A, Zilberstein A, Shulman L, Federman P, Berissi H, Revel M: Interferon action: isolation of nuclease $\mathrm{F}$, a translation inhibitor activated by interferon-induced $\left(2^{\prime}-5^{\prime}\right)$ oligoisoadenylate. FEBS Lett 1978;95:257-264.

18 Nilsen TW, McCandless S, Baglioni C: $2^{\prime}, 5^{\prime}$-oligo(A)-activated endonuclease in $\mathrm{NIH}$ 3T3 mouse cells chronically infected with Moloney murine leukemia virus. Virology 1982;122:498-502.

19 Haller O, Frese M, Kochs G: Mx proteins mediators of innate resistance to RNA viruses. Rev Sci Tech 1998;17:220-230.

20 Itsui Y, Sakamoto N, Kurosaki M, Kanazawa N, Tanabe Y, Koyama T, Takeda Y, Nakagawa M, Kakinuma S, Sekine Y, Maekawa S, Enomoto N, Watanabe M: Expressional screening of interferon-stimulated genes for antiviral activity against hepatitis $\mathrm{C}$ virus replication. J Viral Hepat 2006;13:690-700.

21 Clemens MJ, Elia A: The double-stranded RNA-dependent protein kinase PKR: structure and function. J Interferon Cytokine Res 1997;17:503-524.

22 Pekarek V, Srinivas S, Eskdale J, Gallagher G: IFN lambda-1 (IFN- $\lambda 1 /$ IL-29) induces ELR ${ }^{-}$ CXC chemokine mRNA in human peripheral blood mononuclear cells, in an IFN- $\gamma$ independent manner. Genes Immun 2007;8: 177-180.

23 Ank N, Iversen MB, Bartholdy C, Staeheli P, Hartmann R, Jensen UB, Dagnaes-Hansen F, Thomsen AR, Chen Z, Haugen H, Klucher K, Paludan SR: An important role for type III interferon (IFN- $\lambda /$ IL-28) in TLR-induced antiviral activity. J Immunol 2008;180:2474-2585.

24 Neumann-Haefelin C, Killinger T, Timm J, Southwood S, Mckinney D, Blum HE, Thimme R: Absence of viral escape within a frequently recognized HLA-A26-restricted $\mathrm{CD} 8+\mathrm{T}$ cell epitope targeting the functionally constrained hepatitis C virus NS5A/5B cleavage site. J Gen Virol 2007;88:1986-1991.
Response to Combination Therapy and Mechanism of Viral Clearance
Dig Dis 2013;31:421-425

DOI: $10.1159 / 000355239$ 